\title{
HUBUNGAN TINGKAT HUNIAN PENGUNJUNG HOMESTA Y TERHADAP TINGKAT PENDAPATAN OWNERS DI DESA BONTOMARANNU KECAMATAN ULUERE KABUPATEN BANTAENG PROVINSI SULAWESI SELATAN
}

\author{
Suardi ${ }^{1}$, Muhammad Yusuf Yunus ${ }^{1 *}$ \\ Politeknik Pariwisata Makassar \\ *Email: yusufogan11@gmail.com
}

\begin{abstract}
This study aims: to determine the relationship between visitor occupancy rates and the income level of owners of tourist homestays in Bontomarannu Village, Uluere District, Bantaeng Regency. The analytical method used 1) Simple Regression Analysis which is to find out the form of relationship between visitor occupancy rates $(X)$ and owners (Y) income. 2) Simple correlation analysis is used to determine the closeness of relationship between two variables and to find out the direction of the relationship that occurs. 3) The Determination Coefficient can be used to find out how much the percentage of homestay relationships (variable $X$ ) to owners (Y) income. The results of this study indicate: 1) The number of visitors both local and foreign tourists fluctuate every month, except for 2 consecutive months, namely in April - May 2017 experiencing a decrease due to coinciding with the holy month of Ramadan and Idhul Fitri the majority of people in the village of Bontomarannu, are Muslim. 2) Based on the results of the calculation of correlation analysis, then $r=0.99$, which means that there has been a perfect and positive linear relationship between variables $x$ and $y$ variables. 3) Based on the calculation in table $t$ for a $5 \%$ error at $d f=n-2$, obtained t table 1.701. It turns out that $t$ count is $23.30>t$ table 1.701 thus, then the alternative hypothesis is accepted and null hypothesis is rejected, the conclusion is significant relationship between occupancy rate of visitors and income level of owners.
\end{abstract}

Keywords: occupancy rate visitors, income level owners, bantaeng districts

\section{PENDAHULUAN}

Industri pariwisata merupakan kumpulan usaha pariwisata yang saling terkait dalam rangka menghasilkan barang atau jasa bagi pemenuhan kebutuhan wisatawan dalam penyelenggaraan pariwisata. Pariwisata juga bersifat multi 
dimensi dan multi disiplin seperti disebutkan dalam UU Republik Indonesia Nomor 10 Tahun 2009 Tentang Kepariwisataan. Perkembangan pariwisata dari kegiatan rekreasi menjadi kegiatan ekonomi, menjadikan kegiatan pariwisata tidak berbeda dengan kegiatan industri lainnya yang memiliki mata rantai kegiatan yang demikian kompleks dan melibatkan berbagai sector dengan dimensi fisik geografis, sosial budaya, dan social ekonomi. (Paturusi, 2018:5)

Di Desa Bontomaraanu Kecamatan Uluere Kabupaten Bantaeng Provinsi Sulawesi Selatan sedang dicanangkan program pengembangan Desa Wisata, Pemerintah Kabupaten Bantaeng dalam hal ini Dinas Pariwisata Provinsi Sulawesi Selatan menargetkan beberapa daerah Wisata untuk dikembangkan yang di mana salah satu faktor pendukungnya adalah Usaha Pondok Wisata (Homestay). Melihat fenomena pariwisata yang semakin berkembang dan tingkat kunjungan wisata yang meningkat, maka Homestay adalah pilihan yang tepat untuk pariwisata berbasis masyarakat, di samping harga murah dan dapat terjangkau sekaligus dapat meningkatkan tingkat pendapatan keluarga/masyarakat (Dinas Pariwisata Kabupaten Bantaeng, 2019).

Di Desa Bontomaraanu Kecamatan Uluere Kabupaten Bantaeng Provinsi Sulawesi Selatan sesuai data yang didapat pada Kepala Desa terdapat sebanyak 16 pondok wisata (homestay), atau sebanyak 48 kamar (Dinas Pariwisata Kabupaten Bantaeng, 2019).

Penulis memilih lokasi penelitian dengan studi kasus di Di Desa Bontomaraanu Kecamatan Uluere Kabupaten Bantaeng Provinsi Sulawesi Selatan sebagai salah satu kawasan wisata pesisir pantai yang di mana merupakan salah satu daerah wisata yang sedang dikembangkan Pemerintah Provinsi Sulawesi Selatan dalam program pengembangan wisata. Jumlah kedatangan wisatawan yang meningkat yang dibarengi dengan pembangunan usaha pariwisata terutama usaha akomodasi pondok wisata (homestay).

Terdapat gap antara tingkat hunian pengunjung homestay terhadap tingkat pendapatan owner. Terlihat tingkat hunian tidak terlalu ramai dikunjungi dikarenakan layanan yang kurang prima, fasilitas yang kurang lengkap dan sulitnya akses menuju ke lokasi. Ini yang menyebabkan tingkat pendapatan owner mengalami penurunan dari sisi pemasukan sewa harian, mingguan dan bulanan.

Beberapa penelitian terdahulu yang relevan memiliki persamaan dan perbedaan dengan penelitian ini, antara lain penelitian Nasrul Qadarrocman (2010), Supriyanto (2010), Udhi Sony Prasetyo (2011), Ferry Plearnggara (2012), memiliki persamaan dalam hal variabel yang diamati yaitu variabel dependen tentang pendapatan dan variabel independen tentang hunian. Perbedaan terletak pada hasil penelitian, di mana pada penelitian terdahulu ada beberapa dengan hasil penelitian variabel bebas tidak berpengaruh terhadap variabel terikat. 
Sedangkan dalam penelitian ini, variabel bebas tingkat hunian berpengaruh positif dan signifikan terhadap tingkat pendapatan.

Selanjutnya hasil penelitian terdahulu Satria Adi Nugraha (2012), Alam Pradita Widiatmoko (2009), A. Azinar Muqaddas R., A. Karim Saleh dan Madris (2011), Veronika Winarti Agustiningtyas (2003), Imanda Epata Ginting (2010) dan Badru Tamam (2012) menunjukkan perbedaan dengan penelitian ini, di mana pada penelitian terdahulu variabel terikat (dependent variable) adalah pajak, sedangkan dalam penelitian ini variabel terikat adalah pendapatan. Perbedaan tersebut menjadi keterbaruan antara penelitian ini dengan penelitian sebelumnya.

Pariwisata sebagai suatu industri yang memiliki cakupan yang sangat luas baik dari segi subyek, obyek, maupun aktivitasnya. Perkembangan pariwisata yang semakin pesat disebabkan karena kebutuhan manusia untuk berekreasi semakin meningkat. Berbagai sarana dan prasarana penunjang kegiatan pariwisata bermunculan, tumbuh dan berkembang dengan pesat. Industri pariwisata ini bagaikan jantung yang menggerakan roda perekonomian masyarakat. Tujuan utama dari kegiatan pariwisata yang dilakukannya adalah untuk memperoleh kesenangan atau menghilangkan perasaan tertekan karena rutinitas kerja. Jadi dalam hal ini perolehan kepuasaan dari kegiatan yang dilakukan wisatawan menjadi sangat penting. Selama ini banyak ditemukan defenisi mengenai wisatawan yang masing-masing digunakan oleh negara pengembanganya, sehingga untuk menganalisasinya tidak begitu mudah. Konsep "wisatawan" berasal dari bahasa Sansekerta "wisata" yang berarti "perjalanan" yang sama atau dapat disamakan dengan kata "travel" dalam bahasa Inggris. Jadi orang yang melakukan perjalanan dalam pengertian ini, maka wisatawan sama artinya dengan kata "traveler" karena dalam bahasa Indonesia sudah merupakan kelaziman memakai akhiran "wan" untuk menyatakan orang dengan profesinya, keahliannya, keadaannya jabatannya dan kedudukan seseorang. Jadi kata "wisatawan" dalam beberapa hal berbeda dengan "tourist" dalam bahasa Inggris (RG. Soekadijo, 2015).

Pariwisata menurut Yoeti $(2016 ; 47)$ adalah kegiatan bersenang-senang. Syarat suatu perjalanan disebut sebagai perjalanan wisata, apabila (1) perjalanan di lakukan dari suatu tempat ke tempat lain, di luar tempat kediaman orang itu biasa tinggal; (2) perjalanan yang dilakukan minimal 24 jam atau lebih; (3) tujuan perjalanan semata-mata untuk bersenang-senang, dan tidak untuk mencari nafkah atau bekerja di tempat atau negara yang dikunjungi; dan (4) orang tersebut semata- mata sebagai konsumen di tempat yang dikunjunginya dan uang yang dibelanjakannya dibawa dari negara asalnya atau tempat tinggalnya semula dan bukan dicari atau diperoleh di tempat kota, atau negara yang dikunjunginya. 
Pengertian Pariwisata berdasarkan Undang-Undang RI No. 10 Tahun 2009 tentang pariwisata adalah berbagai macam kegiatan wisata dan didukung berbagai fasilitas serta layanan yang disediakan oleh masyarakat, pengusaha, pemerintah, dan pemerintah daerah. Pariwisata didefenisikan oleh Pitana dan Gayatri (2015:44) sebagai : "The Sum of the phenomena and relationships arising from the interaction of tourists, business, host governments, and host communities, in the process of attracting and hosting these tourists and other visitors". Artinya, pariwisata sebagai keseluruhan fenomena dan hubungan yang muncul dari interaksi para wisatawan, bisnis, pemerintah setempat, komunitas setempat, dalam proses untuk menarik dan menjadi tuan rumah bagi wisatawan dan pengunjung lainnya.

Pada Peraturan Menteri Kebudayaan dan Pariwisata Nomor : PM.86/ HK.501/MKP/2010 Tentang Tata Cara Pendaftaran Usaha Penyedia Akomodasi, dalam peraturan Menteri ini yang dimaksud dengan Usaha adalah setiap tindakan atau kegiatan dalam bidang perekonomian yang dilakukan untuk tujuan memperoleh keuntungan dan/atau laba. Usaha penyediaan akomodasi yang selanjutnya disebut usaha pariwisata adalah usaha penyediaan pelayanan penginapan untuk wisatawan yang dapat dilengkapi dengan pelayanan pariwisata lainnya.

Dalam Materi Pembinaan Homestay dalam rangka "Apresiasi Usaha Masyarakat Bidang Pariwisata" oleh Kementerian Pariwisata disebutkan Pondok Wisata (Homestay) adalah rumah tinggal yang sebagian kamarnya disewakan untuk tamu (wisatawan), merupakan sebuah wadah yang berupa unit hunian sebagai pendukung bagi kawasan di sekitar wisata yang berbentuk pondok penginapan. Produk Homestay berupa bangunan rumah tinggal dengan maksimum 5 kamar dan dihuni oleh pemiliknya. Dalam Peraturan Menteri Kebudayaan dan Pariwisata Nomor : PM.86/HK.501/MKP/2010 Tentang Tata Cara Pendaftaran Usaha Penyedia Akomodasi, disebutkan Pondok Wisata adalah penyediaan akomodasi berupa bangunan rumah tinggal yang dihuni oleh pemiliknya dan dimanfaatkan sebagian untuk disewakan dengan memberikan kesempatan kepada wisatawan untuk berinteraksi dalam kehidupan sehari-hari pemiliknya.

Melihat fenomena pariwisata yang semakin berkembang dan tingkat kunjungan wisata yang meningkat, maka Homestay adalah pilihan yang tepat untuk pariwisata berbasis masyarakat, di samping harga murah dan dapat terjangkau sekaligus dapat meningkatkan tingkat pendapatan keluarga dan masyarakat karena dapat menjadi pendapatan tambahan bagi keluarga dan masyarakat. Wisatawan tinggal bersama tuan rumah (owners) yang tidak lain adalah masyarakat lokal sekitar daerah kawasan wisata, sehingga pertukaran budaya secara tidak langsung terjadi antara tuan rumah (owners) dengan 
wisatawan (tourist) dimana tuan rumah (owners) dapat membantu wisatawan dengan menyediakan layanan wisata lainnya selain penyewaan kamar.

Selama ini banyak ditemukan defenisi mengenai wisatawan yang masingmasing digunakan oleh negara pengembanganya, sehingga untuk menganalisasisnya tidak begitu mudah. Konsep "wisatawan" berasal dari kata dalam bahasa Sansekerta "wisata" yang berarti "perjalanan" yang sama atau dapat disamakan dengan kata "travel" dalam bahasa Inggris. Jadi orang yang melakukan perjalanan dalam pengertian ini, maka wisatawan sama artinya dengan kata "traveler" karena dalam bahasa Indonesia sudah merupakan kelaziman memakai akhiran "wan" untuk menya-takan orang dengan profesinya, keahlian-nya, keadaanya jabatannya dan kedudukan seseorang. Jadi kata "wisatawan" dalam beberapa hal berbeda dengan "tourist" dalam bahasa Inggris (RG. Soekadijo, 2015).

Orang yang melakukan perjalanan wisata disebut wisatawan atau "tourist". Hal ini diungkapkan oleh Pitana (2015:43) yang kemudian menambahkan bahwa batasan terhadap wisatawan juga sangat bervariasi, mulai dari yang umum sampai dengan yang sangat teknis spesifik. United Nation Conference on Travel and Tourism di Roma memberikan batasan yang lebih umum, tetapi dengan meng-gunakan istilah "visitor" (pengunjung), yaitu : "Setiap orang yang mengunjungi Negara yang bukan merupakan tempat tinggalnya, untuk berbagai tujuan, tetapi bukan mencari pekerjaan atau peng-hidupan dari Negara yang dikunjungi" (Nordhaus, 2016).

Pendapatan sangat berpengaruh bagi kelangsungan hidup suatu perusahaan, semakin besar pendapatan yang diperoleh maka semakin besar kemampuan perusahaan untuk membiayai segi pengeluaran dan kegiatankegiatan yang akan dilakukan oleh perusahaan. Bagi seorang produsen pendapatan adalah kenaikan kotor dalam jumlah atau nilai aktiva dan modal, dan biasanya kenaikan tersebut berwujud aliran kas masuk ke unit usaha. Aliran kas masuk ini terjadi terutama akibat penciptaan melalui produksi dan penjualan output perusahaan (Kam, 2018).

Pendapatan juga dapat didefinisikan sebagai jumlah seluruh uang yang diterima oleh seseorang atau rumah tangga selama jangka waktu tertentu (biasanya satu tahun). Pendapatan terdiri dari upah atau penerimaan tenaga kerja, pendapatan dari kekayaan seperti sewa, bunga dan dividen, serta pembayaran transfer atau penerimaan dari pemerintah seperti tunjangan sosial atau asuransi pengangguran (Samuelson dan Nordhaus, 2017).

Pendapatan atau disebut juga income dari seorang warga masyarakat adalah hasil penjualannya dari faktor-faktor produksi yang dimilikinya pada sektor produksi. Dan sektor produksi ini membeli faktor-faktor produksi tersebut untuk digunakan sebagai input proses produksi dengan harga yang berlaku di 
pasar faktor produksi. Harga faktor produksi di pasar faktor produksi (seperti halnya juga untuk barang-barang di pasar barang) ditentukan oleh tarik-menarik antara penawaran dan permintaan (Jaya, 2018).

\section{METODE PENELITIAN}

Penelitian ini menggunakan variabel bebas tingkat hunian pengunjung homestay $(\mathrm{X})$ dan tingkat pendapatan owners (Y). Tingkat hunian pengunjung adalah jumlah pengunjung yang memesan homestay untuk tinggal sementara selama melakukan kunjungan wisata di Desa Bontomarannu Kecamatan Uluere Kabupaten Bantaeng. Indikator tingkat hunian yaitu layanan, fasilitas dan akses lokasi.

Tingkat pendapatan owners adalah perolehan pemasukan berupa uang yang didapat dari pembayaran homestay pengunjung. Indikatornya adalah pembayaran harian, mingguan dan bulanan.

\section{Analisa Regresi Sederhana}

Analisa digunakan untuk mengetahui bentuk hubungan antara tingkat hunian pengunjung $(\mathrm{X})$ dengan pendapatan owners $(\mathrm{Y})$. Regresi sederhana didasarkan pada hubungan fungsional ataupun kausal satu variabel independen dengan satu variabel dependen. Persamaan umum regresi linier sederhana menurut Sugiyono (2017: 169) adalah : $y=a x+b$

\section{Dimana :}

$\mathrm{y}=$ Subjek dalam variabel dependen yang diprediksikan

$a=$ Harga y ketika harga $\mathrm{x}=0$ (harga konstanta)

$b=$ Koefisien regresi atau angka arah

$x=$ Subyek pada variabel independen yang mempunyai nilai tertentu (kompetensi)

Untuk menyelesaikan persamaan regresi Linier dipergunakan rumus sebagai berikut :

$$
\begin{aligned}
& b=\frac{n \sum x y-\left(\sum x\right)\left(\sum y\right)}{n \sum x^{2}-\left(\sum x\right)^{2}} \\
& a=\frac{\sum y-b\left(\sum x\right)}{n}
\end{aligned}
$$




\section{Analisa Korelasi}

Analisa korelasi sederhana diguna-kan untuk mengetahui keeratan hubungan antara dua variabel dan untuk mengetahui arah hubungan yang terjadi. Nilai koefisien $\mathbf{r}$ berkisar antara -1 sampai dengan 1 dengan kriteria sebagai berikut :

1. Jika nilai $r=0$, artinya tidak ada hubungan sama sekali antara variabel $\mathrm{x}$ dan variabel y atau hubungan sangat lemah.

2. Jika nilai $r>0$, artinya telah terjadi hubungan yang linier positif, yaitu makin besar nilai variabel $\mathrm{X}$ (homestay), maka besar pula nilai variabel $\mathrm{Y}$ (pendapatan) atau sebaliknya.

3. Jika $\mathrm{r}<0$, artinya telah terjadi hubungan yang linier negative, yaitu : makin kecil nilai variabel $X$, maka makin besar nilai variabel $Y$ atau sebaliknya.

4. Jika nilai $r=1$, artinya telah terjadi hubungan linier sempurna dan positif antara variabel $X$ dan variabel $Y$, sedangkan $r=-1$ maka terjadi hubungan yang sempurna dan negatif antara variabel $\mathrm{X}$ dan variabel $\mathrm{Y}$.

Rumusan Korelasi product moment menurut Sugiyono (2017), yaitu :

$$
r=\frac{n \sum x y-\left(\sum x\right)\left(\sum y\right)}{\sqrt{\left\{n \sum x^{2}-\left(\sum x\right)^{2}\right\}\left\{\left(n \sum y^{2}-\left(\sum y\right)^{2}\right\}\right]}}
$$

Dimana :

$$
\begin{aligned}
r= & \text { Koefisien korelasi } \\
n= & \text { Jumlah data atau frekuensi penelitian } \\
x= & \text { Variabel bebas (Independen variabel) dalam hal ini adalah tingkat } \\
& \text { hunian pengunjung homestay } \\
y= & \text { Variabel terikat (Dependent variabel) dalam hal ini adalah tingkat } \\
& \text { pendapatan owner. }
\end{aligned}
$$

\section{Koefisien Determinasi}

Analisa ini dapat digunakan untuk mengetahui berapa besar persentase hubungan homestay (variabel X) terhadap pendapatan owners (Y). Rumusnya adalah sebagai berikut :

$$
\begin{aligned}
\mathrm{Kd} & =(\mathbf{r})^{2} \times 100 \% \\
\mathrm{Kd} & =\text { Koefisien determinasi. } \\
\mathbf{r}^{2} & =\text { Kuadrat dari koefisien korelasi. }
\end{aligned}
$$




\section{Uji t (Uji Parsial)}

Untuk menguji signifikansi hubungan, yaitu apakah hubungan yang ditemukan itu berlaku untuk seluruh populasi yang berjumlah 30 orang owners (Sugiyono, 2017), maka perlu di uji signifikansinya. Rumus uji signifikansi korelasi product moment di tunjukkan pada rumus :

$$
t=\frac{r \sqrt{n-2}}{\sqrt{1-r^{2}}}
$$

Di mana :

$$
\begin{aligned}
& \mathbf{r}=\text { Koefisien korelasi } \\
& \mathbf{n}=\text { Jumlah data atau frekuensi penelitian } \\
& \mathbf{r}^{2}=\text { Koefisien determinasi }
\end{aligned}
$$

Harga t hitung tersebut selanjutnya dibandingkan dengan t-tabel.

1. Apabila t hitung $>\mathrm{t}$ tabel, maka ha diterima. Hal ini menunjukkan bahwa variabel $\mathrm{X}$ dan variabel $\mathrm{Y}$ mempunyai hubungan positif.

2. Dengan menentukan tingkat kesalahan alpa dan derajat yang signifikan atau derajat kebebasan (df) sebesar 5\%. Tingkat kesalahan 2 (dua) pihak dan $\mathbf{n}=30$, maka derajat kebebasan $\mathrm{Df}=\mathrm{n}-2, \mathrm{t}$ tersebut $=1,701$ (Sugiyono, 2017).

3. Apabila t hitung < t table, maka ho diterima. Hal ini menunjukkan bahwa variabel $\mathrm{X}$ dan variabel $\mathrm{Y}$ mempunyai hubungan negative.

\section{HASIL DAN PEMBAHASAN}

Hasil penelitian dan pembahasan dalam penelitian ini berfokus pada permasalahan yang diamati untuk dianalisa sesuai dengan hasil olah data dengan menggunakan statistik setelah data ditabulasi dan divalidasi secara normalitas dan reliabilitas. Selanjutnya dilakukan frekuensi untuk menganalisa karakteristik responden dan masing- masing variabel sesuai indikatornya, kemudian dilakukan analisis regresi linier sederhana untuk melihat pengaruh variabel bebas terhadap variabel terikat.

Penentuan harga jual (tarif kamar) sudah termasuk dengan biaya konsumsi (makan siang dan makan malam) dan di hitung berdasarkan penjumlahan tamu atau wisatawan yang menginap pada homestay di Desa Bontomarannu Kecamatan Uluere Kabupaten Bantaeng. Sedangkan untuk tingkat hunian kamar merupakan jumlah kamar terjual dibandingkan dengan seluruh jumlah kamar yang ada pada homestay tersebut.

Penetapan harga jual produk atau jasa (tarif kamar) yang baik akan sangat berpengaruh pada naiknya tingkat hunian kamar (room occupancy) pada 17 
homestay yang ada di Desa Bonto marannu Kecamatan Uluere Kabupaten Bantaeng. Berikut ini tingkat pendapatan owners atau pemilik yang disajikan pada tabel 1 sebagai berikut :

Tabel 1. Pendapatan owners pada 17 homestay yang berada di desa Bontomarannu. Sumber: Hasil Olah Data 2020

\begin{tabular}{|c|l|c|r|}
\hline No. & \multicolumn{1}{|c|}{ Bulan } & $\begin{array}{c}\text { Jumlah } \\
\text { Pengunjung }\end{array}$ & \multicolumn{1}{|c|}{ Pendapatan Owners } \\
\hline 1. & Januari & 820 & 61.500 .000 \\
\hline 2. & Februari & 620 & 46.500 .000 \\
\hline 3. & Maret & 730 & 54.750 .000 \\
\hline 4. & April & 150 & 11.500 .000 \\
\hline 5. & Mei & 80 & 6.000 .000 \\
\hline 6. & Juni & 450 & 33.750 .000 \\
\hline 7. & Juli & 1.200 & 90.000 .000 \\
\hline 8. & Agustus & 530 & 99.750 .000 \\
\hline 9. & September & 700 & 37.500 .000 \\
\hline 10. & Oktober & 650 & 52.500 .000 \\
\hline 11. & Nopember & 870 & 48.750 .000 \\
\hline 12. & Desember & 8.100 & 65.250 .000 \\
\hline & Jumlah & & 607.500 .000 \\
\hline
\end{tabular}

Data yang penulis analisis adalah data yang terdapat pada tabel. Penulis dalam melakukan analisis terhadap kedua variabel yaitu mengenai tingkat hunian homestay (variabel X) dan pendapatan owners (variabel Y). Oleh karena itu, penulis melakukan perhitungan dengan menggunakan koefisien korelasi sebagaimana tercantum pada tabel 2 di bawah ini :

Tabel 2. Perhitungan koefisien kolerasi pengaruh tingkat hunian terhadap pendapatan owners di Desa Bontomarannu Kecamatan Uluere Kabupaten Bantaeng

(Dalam Ribuan Rupiah)

Sumber: Hasil Olah Data 2020

\begin{tabular}{|c|c|c|c|c|c|}
\hline Bulan & $\begin{array}{c}\text { Jumlah } \\
\text { Pengunjung } \\
\text { (X) } \\
\text { (Rp. 000) }\end{array}$ & $\begin{array}{c}\text { Pendapatan } \\
\text { Owners (Y) } \\
\text { (Rp. 000) }\end{array}$ & $\begin{array}{c}\text { XY } \\
\text { (Rp. 000) }\end{array}$ & $\begin{array}{l}\mathrm{X}^{2} \\
(\mathbf{R p} \\
\mathbf{0 0 0})\end{array}$ & $\begin{array}{c}\mathbf{Y}^{2} \\
\text { (Rp. 000) }\end{array}$ \\
\hline 1. & 820 & 61.500 & 50.430 .000 & 672.400 & 3.782 .250 .000 \\
\hline
\end{tabular}




\begin{tabular}{|c|c|c|c|c|c|}
\hline Bulan & $\begin{array}{c}\text { Jumlah } \\
\text { Pengunjung } \\
\text { (X) } \\
\text { (Rp. 000) } \\
\end{array}$ & $\begin{array}{c}\text { Pendapatan } \\
\text { Owners (Y) } \\
\text { (Rp. 000) }\end{array}$ & $\begin{array}{c}\text { XY } \\
\text { (Rp. 000) }\end{array}$ & $\begin{array}{c}\mathbf{X}^{2} \\
(\mathbf{R p} \\
\text { O00) }\end{array}$ & $\begin{array}{c}Y^{2} \\
(\text { Rp. 000) }\end{array}$ \\
\hline 2. & 620 & 46.500 & 28.830 .000 & 384.400 & 2.162 .250 .000 \\
\hline 3. & 730 & 54.750 & 39.967 .500 & 532.900 & 2.997 .562 .500 \\
\hline 4. & 150 & 11.500 & 1.725 .000 & 22.500 & 132.250 .000 \\
\hline 5. & 80 & 6.000 & 480.000 & 6.400 & 36.000 .000 \\
\hline 6. & 450 & 33.750 & 15.187 .500 & 202.500 & 1.139 .062 .500 \\
\hline 7. & 1.200 & 90.000 & 108.000 .000 & 1.440 .000 & 8.100 .000 .000 \\
\hline 8. & 1.330 & 99.750 & 132.667 .500 & 1.768 .900 & 9.950 .062 .500 \\
\hline 9. & 500 & 37.500 & 18.750 .000 & 250.000 & 1.406 .250 .000 \\
\hline 10. & 700 & 52.500 & 36.750 .000 & 490.000 & 2.756 .250 .000 \\
\hline 11. & 650 & 48.750 & 31.687 .500 & 422.500 & 2.376 .562 .500 \\
\hline \multirow[t]{2}{*}{12.} & 870 & 65.250 & 56.767 .500 & 756.900 & 4.257 .562 .500 \\
\hline & 8.100 & 607.750 & 521.242 .500 & 6.949.400 & 39.096.062.500 \\
\hline
\end{tabular}

Dari tabel tersebut di atas, maka dapat diketahui sebagai berikut :

$$
\begin{aligned}
& \mathbf{n}=12 \\
& \mathbf{x}=8.100 \\
& \mathbf{y}=607.750 .000 \\
& \mathbf{x y}=521.242 .500 .000 \\
& \mathrm{x}^{2}=6.949 .400 \\
& \mathrm{y}^{2}=39.096 .062 .500 .000 .000
\end{aligned}
$$

Selanjutnya akan dianalisis menggunakan perhitungan atau rumus di bawah ini :

\section{Regresi Sederhana}

Untuk menyelesakan persamaan regresi linier, maka digunakan rumus sebagai berikut :

$$
\begin{aligned}
& b=\frac{n \sum x y-\left(\sum x\right)\left(\sum y\right)}{n \sum x^{2}-\left(\sum x\right)^{2}} \\
& b=\frac{12(521.242 .500 .000)-(8.100)(607.750 .000)}{12(6.949 .400)-(8.100)^{2}} \\
& b=\frac{6.254 .910 .000 .000-4.922 .775 .000 .000}{83.392 .800-65.610 .000}
\end{aligned}
$$




$$
\begin{aligned}
& b=\frac{1.332 .135 .000 .000}{17.782 .800} \\
& b=74.911,43 \\
& a=\frac{\sum y-b\left(\sum x\right)}{n} \\
& a=\frac{607.750 .000-(74.911,43)(8.100)}{12} \\
& a=\frac{607.750 .000-606.783 .593}{12} \\
& a=\frac{967.407}{12} \\
& a=80.617,23
\end{aligned}
$$

Jadi, nilai regresi sederhana menurut Sugiyono (2017:169) adalah sebagai berikut :

$y=a+b x$

$y=80.617,23+74.911,43(8.100)$

$y=80.617,23+606.782 .593,29$

$y=606.863 .210,52$

Berdasarkan hasil perhitungan di atas, maka di dapatkan nilai regresi sebesar $606.863 .210,52$.

\section{Analisis Korelasi}

Analisis koreasi sederhana digunakan untuk mengetahui keeratan hubungan antara dua variabel dan untuk mengetahui arah hubungan yang terjadi. Adapun rumus korelasi product moment yang digunakan adalah sebagai berikut :

$$
\begin{aligned}
& r=\frac{n \sum x y-\left(\sum x\right)\left(\sum y\right)}{\sqrt{\left\{n \sum x^{2}-\left(\sum x\right)^{2}\left\{n \sum y^{2}-\left(\sum y\right)^{2}\right\}\right.}} \\
& r=\frac{12(521.242 .500)-(8.100)(607.750)}{\sqrt{\{12(6.949 .400)-(65.610 .000)\}\{12(39.096 .062 .500)-(369.360 .062 .500)\}}}
\end{aligned}
$$




$$
\begin{aligned}
& r=\frac{6.254 .910 .00}{\sqrt{\{(83.392 .800)-(65.610 .000)\}\{(46}} \\
& r=\frac{1.332 .135 .000}{\sqrt{(17.782 .800)(99.792 .687 .500)}} \\
& r=\frac{1.332 .135 .000}{\sqrt{1.774 .593 .403 .275 .000 .000}} \\
& r=\frac{1.332 .135 .000}{1.332 .138 .658} \\
& r=0,99
\end{aligned}
$$

Dari perhitungan di atas, maka di dapatkan bahwa $\mathbf{r}=0,99$ artinya telah terjadi hubungan linier yang sempurna dan positif antara variabel $x$ dan variabel $y$.

\section{Uji -t}

Setelah diketahui nilai $\mathbf{r}$ dengan rumus korelasi, maka untuk membuktikan kebenaran hipotesis, maka dilakukan pengujian dengan rumus uji t (t-test) menurut Sugiyono (2017:214) sebagai berikut :

$$
\begin{aligned}
& t=\frac{r \sqrt{n-r^{2}}}{\sqrt{1-r^{2}}} \\
& t=\frac{0,99 \sqrt{12-(0,99)^{2}}}{\sqrt{1-(0,99)^{2}}} \\
& t=\frac{0,99 \sqrt{12-(0,98)}}{\sqrt{1-(0,98)}} \\
& t=\frac{0,99 \sqrt{11,02}}{\sqrt{1-(0,98)}} \\
& t=\frac{0,99(3,32)}{\sqrt{0,02}} \\
& t=\frac{3,29}{0,14} \\
& t=23,30
\end{aligned}
$$


Berdasarkan perhitungan di atas pada tabel t untuk kesalahan 5\% pada df $=\mathrm{n}-2$ diperoleh $\mathrm{t}$ tabel 1,701. Ternyata $\mathrm{t}$ hitung 23,30 $>\mathrm{t}$ tabel 1,701 dengan demikian maka hipotesis alternatif (ha) diterima dan hipotesis nol (ho) di tolak, kesimpulannya terhadap hubungan yang signifikan antara adanya homestay dengan tingkat pendapatan owners.

\section{SIMPULAN}

Berdasarkan analisis hasil penelitian dan pembahasan di atas, maka dapat disimpulkan sebagai berikut :

1. Keadaan pengunjung baik wisawatan lokal maupun mancanegara setiap bulannya mengalami fluktuasi, hanya saja selama 2 bulan berturut-turut yaitu pada bulan April dan Mei 2017 mengalami penurunan diakibatkan bertepatan dengan kegiatan Bulan Suci Ramadhan dan Hari Raya Idhul Fitri yang mayoritas masyarakat di desa Bontomarannu Kecamatan Uluere Kabupaten Bantaeng beragama muslim.

2. Berdasarkan hasil perhitungan analisis korelasi, maka $r=0,99$ yang artinya telah terjadi hubungan linier yang sempurna dan positif antara variabel $\mathrm{x}$ dan variabel y.

3. Berdasarkan perhitungan pada tabel $\mathrm{t}$ untuk kesalahan $5 \%$ pada $\mathrm{df}=\mathrm{n}-2$ diperoleh $\mathrm{t}$ tabel 1,701. Ternyata $\mathrm{t}$ hitung $23,30>\mathrm{t}$ tabel 1,701 dengan demikian, maka hipotesis alternatif (ha) diterima dan hipotesis nol (ho) di tolak, kesimpulannya terhadap hubungan yang signifikan antara tingkat hunian pengunjung dengan tingkat pendapatan pemilik (owners).

\section{DAFTAR PUSTAKA}

Agustianingtyas, Veronika Winarti, 2003. "Analisis Faktor-Faktor Yang Mempengaruhi Penerimaan Pajak Daerah Kabupaten dan Kota Di Propinsi Jawa Tengah Tahun 1998-2001". Tesis.

Dinas Pariwisata Kabupaten Bantaeng. 2019. Statistik Pariwisata 2020. Kementerian Pariwisata Provinsi Sulawesi Selatan.

Ginting, Imanda Epata, 2010."Analisis Penerimaan Pajak Hotel dan Restoran Kabupaten Badung Periode 1996-2006".

Jaya, Sutjipta, 2018. Pariwisata Revolusi di Pulau Dewata. Universitas Udayana. Denpasar.

Kam, 2018. Tourism and World Trade Organization. New Delhi : Discovery Publishing House.

Muqaddas, A. Azinar dan Madris, R., A. Karim Saleh, 2011. "Faktor Penentu Penerimaan Pajak Perhotelan Di Kota Pare-Pare. Jurnal.

Samuelson dan Nordhaus, Putra, 2016. Hukum Bisnis Pariwisata. PT. Refika Aditama. Jl. Mengger Girang No. 98, 40254 Bandung. 
Nugraha, Satria Adi, 2012. “Analisis Terhadap Faktor-Faktor Yang Mempengaruhi Penerimaan Pajak Hotel Studi Kasus Kota Semarang Tahun 2001-2010".

Paturusi, I. 2018. Politik Perencanaan dan Pembangunan Kepariwisataan: Teori Kebijaksanaan dan Prospek Gramedia Jakarta.

Peraturan Menteri Kebudayaan dan Pariwisata Nomor : PM.86/ HK.501/MKP/2010 Tentang Tata Cara Pendaftaran Usaha Penyedia Akomodasi.

Pitana, I Gde dan Gayatri, 2015. Pariwisata Wahana Pelestarian Kebudayaan dan Dinamika Masyarakat Bali. Orasi Pengukuhan Guru Besar dalam Pariwisata, Universitas Udayana.

Pleanggra, Ferry. 2008. "Analisis Pengaruh Jumlah Obyek Wisata, Jumlah Wisatawan dan Pendapatan perkapita Terhadap Pendapatan Retribusi Obyek Pariwisata 35 Kabupaten/Kota di Jawa Tengah". Jurnal Pariwisata. Volume 1, Nomor 1, Tahun 2012, Halaman 1-8.

Prasetyo, Udhi Sony. 2011, "Kontribusi Sektor Pariwisata Terhadap Pendapatan Asli Daerah Kabupaten Karanganyar (Januari 1997- Desember 2007)", Skripsi. Fakultas Ekonomi, Universitas Sebelas Maret.

Qadarrochman, Nasrul, 2010, "Analisis Penerimaan Daerah Dari Sektor Pariwisata Di Kota Semarang dan Faktor Yang Mempengaruhinya". Skripsi. Fakultas Ekonomi, Universitas Diponegoro.

Soekadijo, R.G., 2015, Anatomi Pariwisata, Jakarta Gremedia Pustaka Utama Santosa, SP. 2001. Bahan Paparan untuk Gubernur Bali. Mimeo

Sugiyono, 2016. Metodologi Penelitian Kualitatif dan Kuantitatif. Penerbit Rajawali Press, Jakarta.

Supriyanto. 2010, “Analisis Faktor-Faktor Yang Mempengaruhi Kontribusi Sektor Pariwisata Terhadap Pertumbuhan Ekonomi di Kabupaten Wonogiri Tahun 2001-2008". Skripsi. Fakultas Ekonomi, Universitas Sebelas Maret.

Tamam, Badru, 2012. "Analisis Faktor-Faktor Yang Mempengaruhi Penerimaan Pajak Hotel dan Restoran Di Provinsi DKI Jakarta Periode 1997-2008".

Undang-Undang RI No. 10 Tahun 2009 tentang Pariwisata.

Widiatmoko, Alam Pradita, 2009. "Analisis Pajak Hotel dan Potensi Pengembangannya". Studi Kasus Kabupaten Semarang.

Yoeti, Oka H.A. 2016. Ilmu Pariwisata: Sejarah Perkembangan, dan Prospeknya. Jakarta: Penerbit Pertja. 